
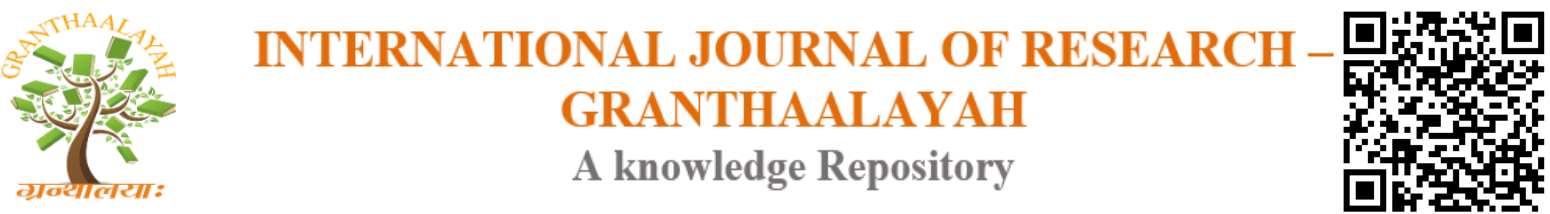

Science

\title{
CHALLENGES OF POTABLE WATER SUPPLY MANAGEMENT IN BAFUT SUB-DIVISION, NORTH WEST REGION OF CAMEROON
}

\author{
Modeste Lumnwi ${ }^{1}$, Wilson Yetoh Fantong ${ }^{2}$, Samuel Ndonwi Ayonghe ${ }^{3}$ \\ ${ }^{1}$ Department of Environmental Science, Faculty of Science, University of Buea, Box 63 BUEA \\ Cameroon \\ ${ }^{2}$ Institute of Geological and Mining Research (IRGM), Hydrological Research Centre, Yaoundé, \\ Box 4110 Yaoundé Cameroon \\ ${ }^{3}$ UB Interdisciplinary Climate Change Laboratory, Department of Environmental Science, \\ Faculty of Science, University of Buea, Box 63 Buea Cameroon
}

\begin{abstract}
Drinking water if not monitored could be a vehicle for diseases of public health concern in Bafut Sub-Division Cameroon. The present study sought to assess the challenges faced by community water supply schemes based on the evaluation of quality and quantity. This study was a cross sectional community survey marked by field survey involving mapping, discharge measurement, potable water samples collection (springs, streams, rain, wells and boreholes) and laboratory analysis. Twelve pipe born water supply schemes and thirty-eight water sources were appraised within two intervals (March-July 2015 and October 2017-March 2018). Chemical analysis was done using an Ion Chromatography and microbial analyses using the presumptive test method and standard plate count. Hospital registers were reviewed on prevalence of water borne diseases. The results showed that major challenges of water supply included; dilapidated pipes, spring inputs and climate variability. Hydro chemical faces were sodium bicarbonate and calcium chloride water types. A total Coliform count of 43 to $>1100$ per 100ml was recorded for March and July 2015 and 0-236Tcfu in March 2018. Escherichia coli and Salmonella typhi were probably responsible for high rate of water borne diseases. There is need to develop standardize integrated water management plan in this area.
\end{abstract}

Keywords: Challenges; Potable Water; Quality; Quantity; Supply Management; Water Sources

Cite This Article: Modeste Lumnwi, Wilson Yetoh Fantong, and Samuel Ndonwi Ayonghe. (2018). "CHALLENGES OF POTABLE WATER SUPPLY MANAGEMENT IN BAFUT SUBDIVISION, NORTH WEST REGION OF CAMEROON.” International Journal of Research Granthaalayah, 6(10), 256-273. https://doi.org/10.29121/granthaalayah.v6.i10.2018.1192.

\section{Introduction}

Water is an essential commodity for the existence of life on Earth, but the expanding human population and climate change have caused its demand to exceed supply and quantitative depletion 
in many parts of the world (Patricia, 2014, Scott and Richard, 2015). Fresh water which is often used for drinking now occupies less than $3 \%$ of water out of 326 trillion gallons of water on Earth (Michel, 2017). As developmental projects in developing countries, provision and access to safe drinking water has increased over the last decade but approximately one billion people still lack safe drinking water throughout the world. Sustainable Development Goal (SDG) six ("Ensure availability and sustainable management of water and sanitation for all targets to achieve universal and equitable access to safe and affordable drinking water for all by 2030. In Cameroon as at 2006, $70 \%$ of the population had access to safe drinking water and a supply coverage of $88 \%$ in urban areas and 47\% in rural areas (Ako et al., 2010).

It is important to investigate the water quality so as to endorse a scheme for drinking and sustainable management (CAWST, 2009). Human needs for water vary per daily consumption of water and investigating on water quantity will improve on the usage and valorization of this natural resource. Groundwater quantities are greatly influenced by wet and dry periods, with water tables rising when the climate is wetter and falling when climate is dry. One effect of rising and falling water tables is rising and falling of stream levels, springs discharges and groundwater in wells and boreholes (Gereta, 2004). The negative impacts from the variations are mostly on the vulnerable population of women and children who are forced to travel long distances to fetch for water.

WHO (2014) defines an improved drinking-water source as a source that by the nature of its construction and design, adequately protects the source from outside contamination, by fecal matter in particular (WHO, 2014). Drinking water from these sources should have a high probability of being free of fecal indicator bacteria and, if possible, should meet the WHO quality guidelines for drinking-water. Conversely, unimproved drinking-water sources are vulnerable to permanent or temporary water-quality deterioration and often do not meet the WHO guideline values for safe drinking water.

Insufficient access to safe water supply and adequate sanitation has been reported as the root cause of many diseases that afflict Africa and a contributing factor to high infant and maternal mortality rates (Ako et al., 2010). Thus the performance of most water resources especially at the community level are dwindling because of unsustainability, mainly due to poor financial management and lack of trust (Strasser, 2000). Therefore, rural water supply schemes should deliver the expected service to users for a reasonable period of time in terms of quality, quantity, accessibility, coverage, affordability and continuity (Harvey, 2004).

Changing climatic conditions affect water quality and quantity, thus leaving the study area at risk of water insecurity (Ngwa, 1982). Water related diseases represent about two-thirds of all the diseases in Cameroon and are responsible for approximately $50 \%$ of the cases of deaths recorded (Katte et al., 2003). The combination of low access to safe water and poor sanitation conditions is made evident by Cameroon's recent history of cholera outbreaks and the burden of disease attributed to diarrheal illness in the country. Despite Cameroon's greatest cholera outbreaks, majority of water quality studies conducted in Cameroon have mostly been centered in the Far North Region and not much done in the North West region particularly in Bafut sub division (Djaouda et al., 2014, Takem, 2010, Nola et al., 2013). 
Despite this situation, only few recent studies have been carried out on the microbial quality of drinking-water, restricted to major cities of Douala (Ndjama et al., 2008; Ako et al., 2009), Yaounde (Kuitcha et al., 2010; Ateba et al., 2012) and Dschang (Katte et al., 2003; Temgoua, 2011). These studies demonstrated exceptionally high and unacceptable levels of bacteriological contamination of most drinking-water supplies. It is thus important to assess rural water supply schemes where demography and climate variability are real.

The study was limited to Bafut Sub Division situated between longitude $10^{\circ} 06 \mathrm{~N}$ and latitude $6^{\circ}$ '10E North West Region of Cameroon (Figure 1). The study area is characterized by a humid subEquatorial climate with nine months of rainfall from November to March with an annual rainfall of $2400 \mathrm{~mm}$ which recharges groundwater and a dry season from March to October (CDP, 2011). The population of Bafut has been on an increase from the year 1953 with a population of over 19,000, proceeded by 80,305 in 1987 to 129,363 inhabitants in 2011 following a census made from council development plan with support from the National Community Driven Development Program (PNDP) (CDP, 2011). The study area has a population growth rate of about $2.9 \%$ per annum. This population increase triggered this work, which sought to determine the quantity and quality of water available for this growing population and to determine whether the service delivery of catchments are satisfactory.

Developmental issues such as water supply and management for these growing population are handled by development associations who financed water projects through Water Maintenance Committee (WMC) (CDP, 2011). However there has been limited studies carried out on the quality and quantity of potable water consumed by the population, thus creating the necessity to have a close look on how operational water supply schemes are management and the quality of water they supply.

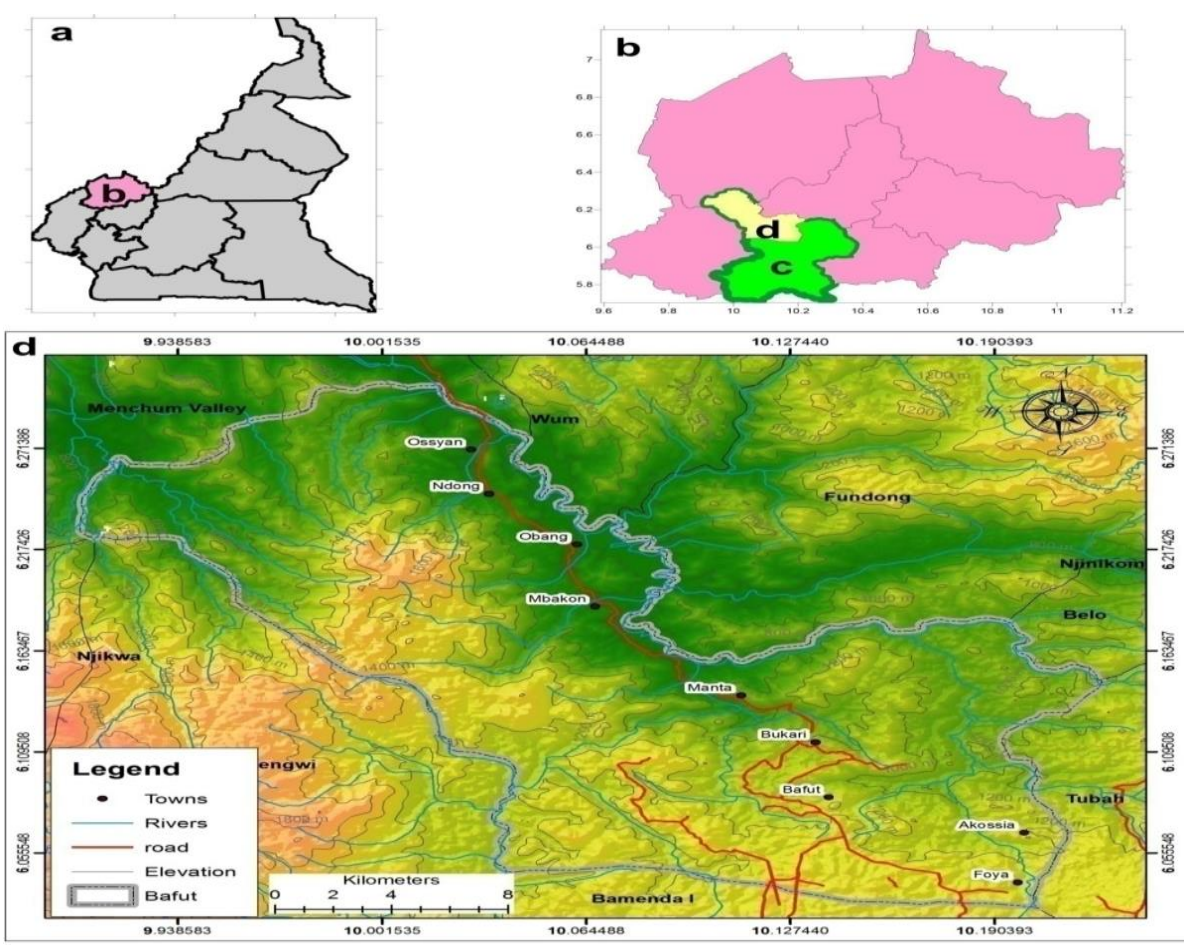

Figure 1: Location of Bafut Sub- Division (Adapted from CAMGIS Bamenda, 2015) 


\section{Materials and Methods}

\section{Study Design}

The present study assesses potable water resources and their suitability for drinking with the challenges faced in water supply management. This study was carried out in two intervals, January- August 2015 and October 2017-March 2018. During the first interval the study was centered in South East Bafut which is composed of the most densely populated areas with administrative units and within the second interval the study cut across the entire Sub-Division. Sample collection, preservation and transportation was done following American Public Health Association standards, in sterilized plastic bottles $(1500 \mathrm{ml}$ and $500 \mathrm{ml})$ after thorough rinsing directly from the respective water sources (taps, wells, streams, boreholes and rain) (APHA, 1998. A cloistered cold flask with ice blocks was used for sample preservation and transported to "Laboratoire d'Analyse Geochemie et 1'eau" (LAGE) of the Institute of Geology and Mining Research (IRGM) Yaounde. Samples for microbial analyses were analyzed within 24 hours after transportation as used in a study carried out by Omam and Ayonghe, (2015) assessing the potability of some sachet water brands sold in Cameroon. All samples collected were labeled appropriately for physico-chemical and microbial analyses.

A questionnaire design containing both structured and non-structured questions as used by Henry, (2007) in his study assessing the Challenges of Water Supply in Ghana. A stratified purposive and random sampling technique as used by Regassa (2016) was adopted as a method of administering the questionnaires.

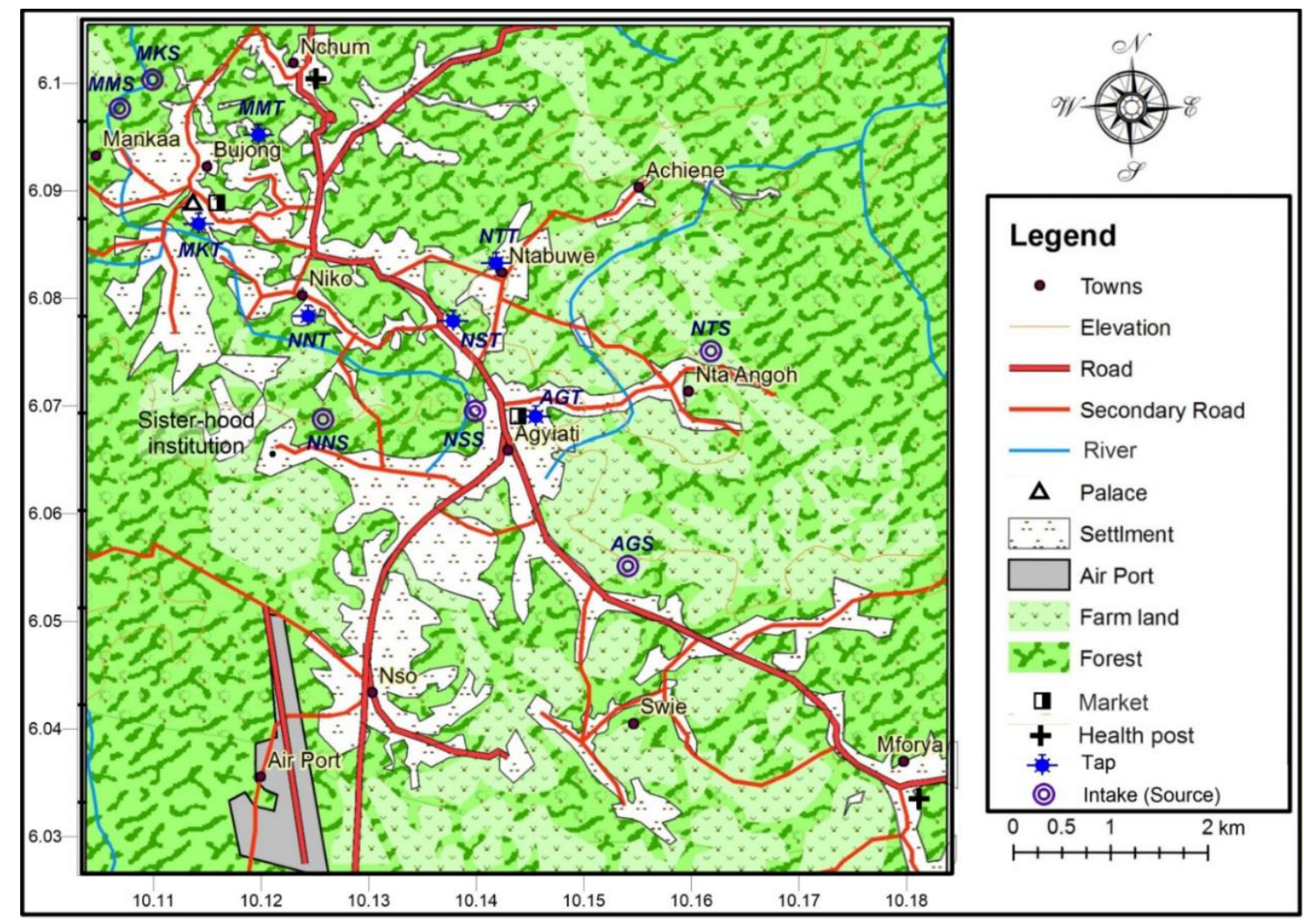

Figure 2: Showing locations of sample collection points 
Four hundred Questionnaires were administered to nine communities in South East Bafut (Mbebali, Mankaha, Bujung, Niko, Njinteh, Nem, Ntabuwe, Agyati and Swie) and 40 to members of WMC to have their perception on prevailing water conditions and demand (Figure 2). Twelve pipe born water supply schemes and 38 other supplementary potable water sources were appraised for qualitative analyses amongst which six schemes where assessed for quantitative analyses from South East Bafut.

\section{Discharge Analysis}

Discharge measurements were carried out for 30 days (March, 2015) using a 20 liters bucket and a stop watch per seconds to obtain the mean daily discharge. Population water demand was derived from questionnaires administered based on the amount of water each individual in a household uses daily as used by Henry, (2007). Supply coverage was determined from discharge and population demand.

\section{Physico-Chemical Analysis}

Physical parameters analyzed included water temperature, atmospheric temperature, electrical conductivity and $\mathrm{pH}$, measured insitu using a PT154ET thermometer, Cond 330i/set and WTW $315 \mathrm{i} \mathrm{pH}$ meter respectively. Thirty samples were collected in March (24) and July (6), 2015 for physico-chemical analyses using an Ion Chromatography (ICS) (Small et al., 1975) and fourty two in March 2018 for microbial assessment. The identities of the cations and anions were determined by their retention time and their concentration by a calibration curve. The device used was ICS900 and ICS-1100 Dionex model. The charge balance for reliability of chemical measurement calculated was within the acceptable limit of $\pm 5 \%$ (Dominico et al., 1990).

\section{Analyses for Microbial Quality}

During the first interval, a presumptive test was carried out on 12 samples in March 2015 and 6 samples in July, 2015 to detect the Most Probable Number (MPN) of bacteria present in each water sample (Benson, 2002) in the Life Science Laboratory of the University of Buea. A medium was prepared using lactose broth following manufacturers guide and distributed with a pipette into 103 Durham tubes with 9 tubes representing a sample; 3 Durham tubes of Double Strength Lactose Broth (DSLB) and 6 of single strength lactose broth (SSLB) and autoclaved for 15minutes. A pipette was used to drop $10 \mathrm{ml}$ of water sample into each DSLB tubes and $1 \mathrm{ml}$ into a set of 3 Durham tubes; $0.1 \mathrm{ml}$ of water drop into a set of 3tubes SSLB per sample. They were incubated at $35^{\circ} \mathrm{C}$ for 24 hours and examined to obtain the number of tubes with $10 \%$ or more gas formation. The MPN of coliform was determined based on the American Public Health Association standards manual (APHA, 1998).

Cultural analysis using standard plate count (SPC) and the light microscope was used for microbial and bacteriological analyses using MacConkey and SS Agar medium during the second interval of the study (March 2018). Fourty two potable water schemes were sampled (15 springs, 13 taps, 6 streams, 1 borehole, 5 wells and 2 rain water sources) from 31communities. Stock culture and subculture on nutrient agar were done to obtain fresh colonies for microscopic analysis. Preparation of nutrient agar was done following manufacturer's instructions and APHA manual of 1978 and 1992. Violet red bile lactose agar and Macconkey agar was used to isolate Echerichia coli from other gram negative pathogens present in water samples that show the presence of coliform, while SS agar was used to isolate Salmonella. The mediums were prepared under a 
Bunsen and allowed to cool at $47^{\circ} \mathrm{C}$ and inoculated into corresponding labeled cultured plates of water samples and incubated for $24-48$ hours at $35^{\circ} \mathrm{C}-37^{\circ} \mathrm{C}$ (Druce et al., 1957). Samples were also centrifuge and inoculated on three nutrient agar used. Colony forming unit (cfu/ml) per milliliters was calculated by multiplying the average number of colonies per plate by the dilution factor of the inoculated sample. The average number of colonies per plate was derived by dividing the total number of colonies of all plates that were inoculated by the same dilution volume and dividing the sum by the two plates used. For quality control and reliability microscopy gram control was done on all isolated slides from centrifuge samples and on isolated colonies. Microscopic analysis was done after cultural quantification of bacteria on gram stained slides. Slides were examined on a light microscope using 100x oil immersion objectives to differentiate gram negative from gram positive bacteria. The appearance of pink color signifies a positive result for Escherichia coli and blackish color positive for Salmonella (Njunda et al, 2013).

Hospital registers were reviewed from 2003-2017 on the prevalence of water borne diseases and causative agents in within the months of October 2017-December 2017.

\section{Statistical Analysis of Data}

SPSS version 22, epi info version 9.1 and Pearson correlation coefficient were used to establish the relationship between water variables and the Pipers plot to determine water type (Piper, 1944). Climatic data was obtained from the Meteorological Station at Bafut airport to establish rainfall trends.

\section{Results and Discussions}

\section{Challenges of Water Supply}

The results indicated that the population uses Gravitational (98\%) and electrical pumps (2\%) water canalization systems. The study established two levels of factors causing water unavailability in the study area; namely internal (factors within the utility) and external (factors outside the utility). Within the utility, there was poor governance which was portrayed by, unavailability of performance reports and lack of incentives to workers (low salaries), low tariffs collection which was aggravated by illegal connections rated at $15 \%$ and faults (dilapidated pipes) which eventually led to high non-revenue water (Table 1)

Table 1: Challenges of potable water supply

\begin{tabular}{|l|l|}
\hline Causes for break down in water supply & Percentage \\
\hline Poor slope gradient & 2.5 \\
\hline Dilapidated pipes and activities carried out at catchment area & 42.5 \\
\hline Leakages and increasing population with partitioning & 37 \\
\hline illegal home connection & 15 \\
\hline
\end{tabular}

The study established two levels of factors challenging potable water supply mainly internal which is within the management of the utility and external which could be natural factors. Within the supply scheme there is poor management marked by Farming and logging carried out within catchment areas, dilapidated pipes (remarkably in Niko, Njinteh, Nsem Ntabuwe communities), water partitioning, leakages from reservoirs, slope gradient, pump failure and illegal home connections. 
This was aggravated by a lack of incentives to caretakers of the schemes sponsored by the unavailability of performance and financial reports. Reservoir chambers and tanks accounted for poor sanitation as most of the reservoirs and chambers (about 85\%) were not regularly cleaned, and about $75 \%$ of the catchments were located close to toilets while some catchment areas served as grazing land for cattle. Despite these factors, the study identified external factors that impinge water availability in the community such as, population growth pegged at $2.9 \%$ annually and natural factors such as climate variability.

The mean annual rainfall of Bafut observed a $20 \%$ decrease from $2825 \mathrm{~mm}$ in 1995 to $2250 \mathrm{~mm}$ in 2015 , creating an impact on ground water resources as it could lead to a decrease in water level (Figure 2).

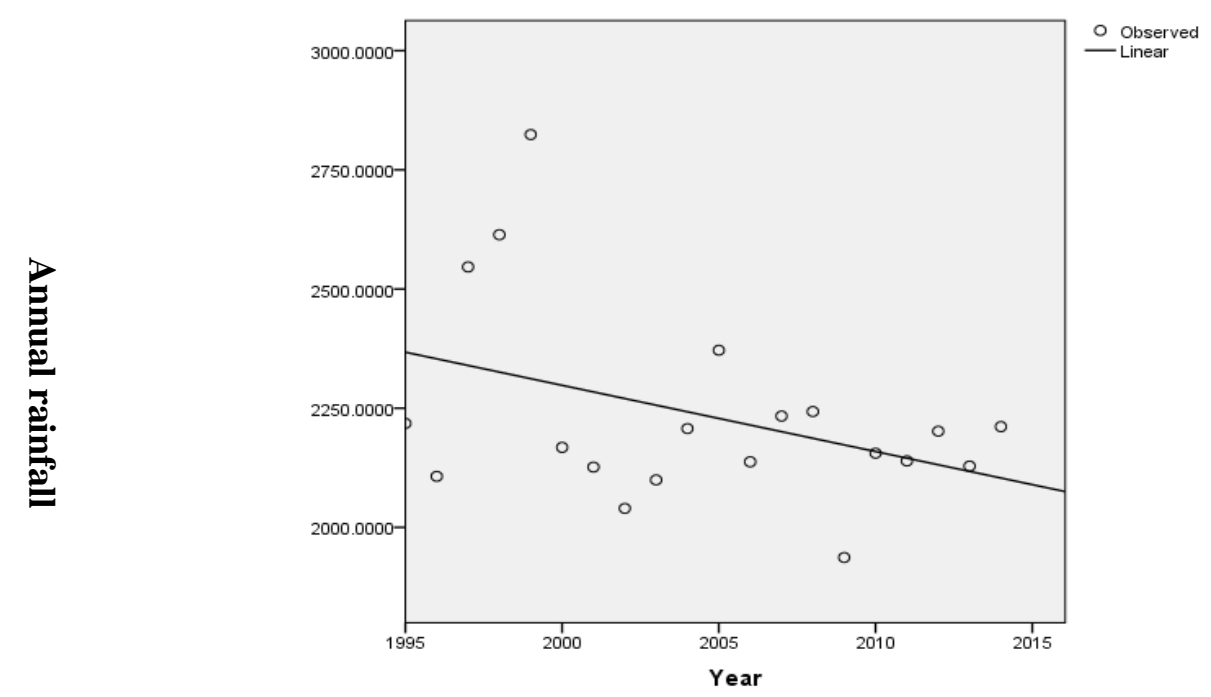

Figure 3: Plot of total annual rainfall from 1995 to 2014

\section{Water Discharge}

The results for the analysis of water discharge on daily bases indicated that $83.3 \%$ of the six catchments within the study area experienced an increase in water discharge particularly Mbebali, Mankaha/ Bujung and Niko/Njinteh from the period of installation till present, while $16.6 \%$ of the supply schemes experience a decrease in discharge rates mainly from Ntabuwe (Table 2).

Table 2: Discharge rate of water supply schemes

\begin{tabular}{|l|l|l|l|l|l|l|}
\hline Community & $\begin{array}{c}\text { Installed } \\
\text { capacity }\end{array}$ & $\begin{array}{c}\text { Calculated } \\
\text { mean litters } \\
\text { per day }\end{array}$ & $\begin{array}{c}\text { Rate of } \\
\text { change }\end{array}$ & $\begin{array}{c}\text { \% } \\
\text { change }\end{array}$ & $\begin{array}{c}\text { Water per } \\
\text { person in a } \\
\text { day(liters) }\end{array}$ & $\begin{array}{c}\text { Total } \\
\text { population } \\
\text { using supply } \\
\text { scheme }\end{array}$ \\
\hline Mbebali & 18,144 & 64,800 & 46,656 & $\mathbf{7 2 \%}$ & 6.82 & 9,500 \\
\hline Mankaha/Bujung & 16,416 & 36,288 & 19,872 & $54.8 \%$ & 14.52 & 2,500 \\
\hline Niko/ Njinteh & 19,872 & 43,200 & 23,328 & $54 \%$ & 12.17 & 3,550 \\
\hline Nsem & 16,416 & 34,560 & 18,144 & $52.5 \%$ & $\mathbf{1 7 . 2 8}$ & 2,000 \\
\hline Agyati & 2,592 & 4,320 & 1,728 & $40 \%$ & 0.39 & 11,000 \\
\hline Ntabuwe & 19,872 & 13,824 & $-6,048$ & $\mathbf{- 4 3 . 8 \%}$ & 9.21 & 1,500 \\
\hline Total & $\mathbf{9 3 , 3 1 2}$ & $\mathbf{1 9 6 , 9 9 2}$ & $\mathbf{1 0 3 , 6 8 0}$ & $\mathbf{5 2 . 6 \%}$ & $\mathbf{6 . 5}$ & 1,000 \\
\hline
\end{tabular}


In a whole the study area observed a $52.6 \%$ (103,680 1/day) increase in discharge per day from 1981 to 2015 with about 6.5 liters of water available for an individual per day (Table 2). Comparing daily water demand (Table 3) and discharge, daily water demand (206,6282.5 L) was greater than daily catchment discharge (196,992 L).

Table 3: Demand and supply measurement

\begin{tabular}{|l|l|l|l|l|}
\hline \multicolumn{1}{|c|}{ Community } & \multicolumn{1}{|c|}{$\begin{array}{c}\text { Calculated Present daily } \\
\text { demand in litters }\end{array}$} & $\begin{array}{c}\text { \% } \\
\text { demand }\end{array}$ & $\begin{array}{c}\text { Mean daily } \\
\text { supply }\end{array}$ & $\begin{array}{c}\text { Supply coverage } \\
(\%)\end{array}$ \\
\hline Mbebali & 505,970 & 24.5 & 64,800 & 12.8 \\
\hline Mankaha/Bujung & 198,375 & 9.6 & 36,288 & 18.2 \\
\hline Niko/ Njinteh & $238,737.5$ & 11.6 & 43,200 & 1.8 \\
\hline Nsem & 160,000 & 7.7 & 34,560 & $\mathbf{2 1 . 6}$ \\
\hline Agyati & 888,800 & 43 & 4,320 & 0.48 \\
\hline Ntabuwe & 74,400 & 3.6 & 13,824 & 18.6 \\
\hline Total & $\mathbf{2 0 6 6 2 8 2 . 5}$ & 100 & $\mathbf{1 9 6 9 9 2}$ & $\mathbf{9 . 5}$ \\
\hline
\end{tabular}

Agyati community had the highest demand (43\%). Infact this was in line with a supply coverage of $9.5 \%$, and greatest supply coverage covered by Nsem scheme (21.6\%).

\section{Hydrochemistry of Water Sources}

Physico- chemical analysis showed that water temperature varied from 21 to $23^{\circ} \mathrm{C}$ with a mean temperature of $22.2^{\circ} \mathrm{C}, 22.15^{\circ} \mathrm{C}$ for springs and $22.51^{\circ} \mathrm{C}$ for taps. $\mathrm{pH}$ values ranged between 5.75 - 7.75 with a mean of 6.78 , indicating acidity (Table 4). Electrical conductivity varied between $15.7 \mu \mathrm{s} / \mathrm{cm}$ to $171 \mu \mathrm{S} / \mathrm{cm}$ and TDS between 0.4 to $23.6 \mathrm{mg} / \mathrm{l}$.

The concentrations of ions were minimal in water samples which could be as a result of low mineralization from short duration of water rock interaction. In decreasing order, the relative concentration of cations stood at $\mathrm{Mg}^{2+}>\mathrm{Ca}^{2+}>\mathrm{Na}^{2+}>\mathrm{k}^{+}>\mathrm{NH}_{4}{ }^{+}$while that of anions stood at $\mathrm{HCO}^{-}$ ${ }_{3}>\mathrm{Cl}^{-}>\mathrm{F}^{-}>\mathrm{SO}_{4}^{-}>\mathrm{NO}_{3}{ }^{-}>\mathrm{PO}_{4}^{-}$. The mean concentration of magnesium stood at $0.5 \mathrm{meq} / \mathrm{l}$ ranging from $0.02 \mathrm{meq} / 1$ to $2.2 \mathrm{meq} / 1$, with highest concentration from Mankaha water source $(2.2 \mathrm{meq} / \mathrm{l})$. Bicarbonate ranged from $0.13 \mathrm{meq} / 1$ to $1.9 \mathrm{meq} / \mathrm{l}$ having a mean concentration of $0.72 \mathrm{meq} / \mathrm{l}$. Sodium ion concentration ranged from $0.7 \mathrm{mg} / \mathrm{l}$ to $1.7 \mathrm{mg} / \mathrm{l}$ (Table 4 ) in tap water and $0.6 \mathrm{mg} / \mathrm{l}$ to $1.9 \mathrm{mg} / \mathrm{l}$ in spring water with a mean concentration of $1.31 \mathrm{mg} / \mathrm{l}$.

Table 4: Physical and chemical parameters of water samples

\begin{tabular}{|c|c|c|c|c|c|c|c|c|c|c|c|c|c|c|}
\hline Samples & pH & EC & TDS & $\mathrm{Na}^{+}$ & $\mathrm{NH}_{4}{ }^{+}$ & $\mathbf{K}^{+}$ & $\mathrm{Mg}^{2+}$ & $\mathrm{Ca}^{2+}$ & $F^{-}$ & $\mathrm{Cl}^{-}$ & $\mathrm{NO}_{3}^{-}$ & $\begin{array}{c}\mathbf{P O}^{3-} \\
4\end{array}$ & $\mathrm{SO}^{2}{ }_{4}^{-}$ & $\begin{array}{c}\mathrm{HCO} \\
3\end{array}$ \\
\hline Unit & & $\mu \mathrm{S} / \mathrm{cm}$ & $\mathrm{mg} / \mathrm{L}$ & $\mathrm{Mg} / \mathrm{l}$ & $\mathrm{Mg} / \mathrm{l}$ & $\mathrm{Mg} / \mathrm{l}$ & $\mathrm{Mg} / \mathrm{l}$ & $\mathrm{Mg} / \mathrm{l}$ & $\mathrm{Mg} / \mathrm{l}$ & $\mathrm{Mg} / \mathrm{l}$ & $\mathrm{Mg} / \mathrm{l}$ & $\mathrm{Mg} / \mathrm{l}$ & $\mathrm{Mg} / \mathrm{l}$ & $\mathrm{Mg} / \mathrm{l}$ \\
\hline AGT & 6.75 & 15.7 & 0.4 & 0.7 & 0.06 & 1.07 & 0.25 & 0.09 & 0.04 & 0.03 & 0.02 & 0.02 & 0.04 & 8.1 \\
\hline AGS & 6.74 & 17.3 & 0.8 & 0.77 & 0.04 & 1.16 & 0.39 & 0.22 & 0.08 & 0.23 & 0.07 & ND & 0.07 & 8.8 \\
\hline MKS & 7.43 & 168 & 0.4 & 3.5 & 0.03 & 3.65 & 25.94 & 36.21 & 0.06 & 0.09 & 0.55 & 0.12 & 0.04 & 116.3 \\
\hline MKT & 7.59 & 171 & 0.4 & 1.72 & 0.08 & 1.81 & 13.06 & 18.29 & 0.08 & 0.06 & 0.84 & 0.17 & 0.06 & 114.3 \\
\hline MMS & 6.35 & 42.8 & 1.4 & 1.91 & 0 & 1.45 & 1.91 & 1.72 & 0.04 & 0.1 & 0.02 & 0.08 & 0.09 & 26.3 \\
\hline MMT & 7.63 & 130 & 1.2 & 1.72 & 0.03 & 1.35 & 10.52 & 10.93 & 0.07 & 0.08 & 0.82 & 0.08 & 0.05 & 84.7 \\
\hline NSS & 7.75 & 88 & 3.6 & 0.74 & 0.02 & 1.01 & 6.55 & 9.12 & 0.07 & 0.07 & 1.44 & 0.06 & 0.08 & 56.4 \\
\hline NST & 6.6 & 78.4 & 2.4 & 0.89 & 0.08 & 0.9 & 5.76 & 8.01 & 0.07 & 0.11 & 1.55 & 0.04 & 0.06 & 49.5 \\
\hline NTS & 6.88 & 24.4 & 4 & 0.68 & 0.03 & 0.61 & 1.38 & 1.1 & 0.03 & 0.06 & 0 & 0.05 & 0.17 & 14.4 \\
\hline
\end{tabular}


[Lumnwi et. al., Vol.6 (Iss.10): October 2018]

(Received: September 18, 2018 - Accepted: October 27, 2018)
ISSN- 2350-0530(O), ISSN- 2394-3629(P)

DOI: 10.5281/zenodo.1491883

\begin{tabular}{|l|l|l|l|l|l|l|l|l|l|l|l|l|l|l|}
\hline NTT & 6.57 & 30 & 2.4 & 0.75 & 0.08 & 0.88 & 1.82 & 1.39 & 0.05 & 0.06 & 0.12 & ND & 0.22 & 17 \\
\hline NNS & 6.58 & 29.7 & 23.6 & 1.51 & 0.03 & 1.23 & 1.70 & 1.82 & 0.09 & 0.24 & 0.14 & 0.33 & 0.12 & 16.8 \\
\hline NNT & 6.44 & 28.1 & 1.2 & 0.83 & 0.88 & 1.82 & 1.39 & 0.05 & 0.06 & 0.08 & 0.12 & 0.03 & 0.12 & 16.9 \\
\hline
\end{tabular}

$\mathrm{ND}=$ None detectable

The mean concentration of sodium was more in spring water $(1.51 \mathrm{mg} / \mathrm{l})$ than in the tap water $(1.09 \mathrm{mg} / \mathrm{l})$ with Bujung/Mankaha springs $(3.5 \mathrm{mg} / \mathrm{l})$ indicating the highest concentrations.

Chloride ranged from 0.03mg/l (Agyati tap, Mankah/Bujung tap, Ntabuwe spring and Ntabuwe tap) to $0.1 \mathrm{mg} / \mathrm{l}$ (Mankaha/Bujung) with a mean of $0.1 \mathrm{mg} / \mathrm{l}$ mean while Nitrate had a mean concentration of $0.47 \mathrm{mg} / \mathrm{l}$. Correlation values indicated a positive relationship between $\mathrm{HCO}^{3-}$ with $\mathrm{Ca}, \mathrm{Mg}, \mathrm{Na}$ and $\mathrm{K}$, values of $0.91,0.92,0.72$ and 0.7 respectively. The dominant water types were $\mathrm{Ca}^{+}-\mathrm{Cl}^{-}$, and $\mathrm{Na}^{+}+\mathrm{K}^{+}-\mathrm{HCO}_{3}$ (Figure 3).

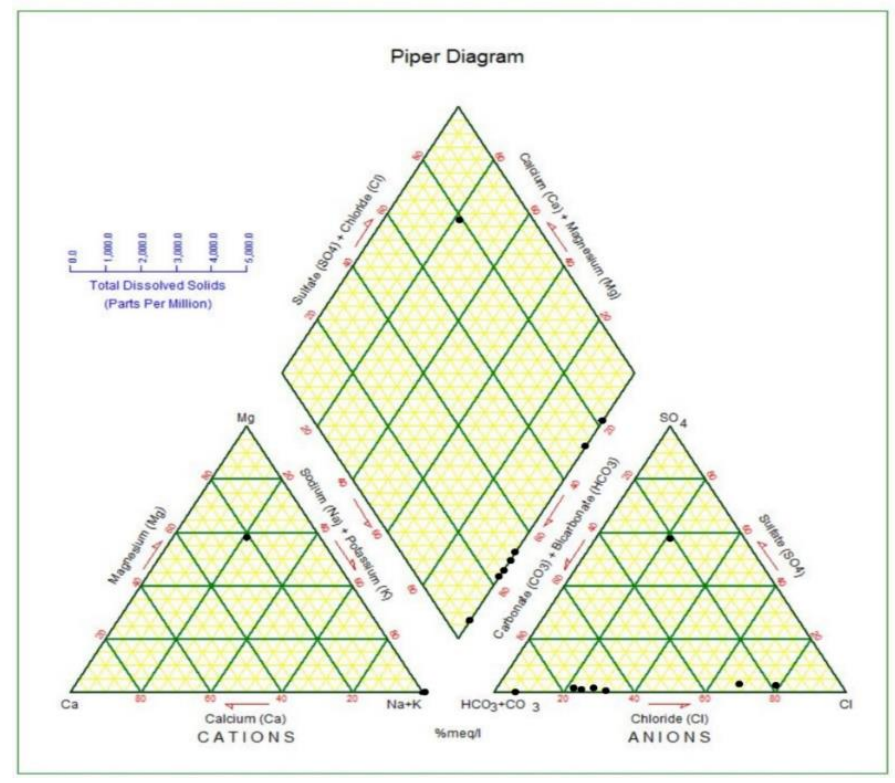

Figure 4: Piper's diagram showing various water types

Table 5: Correlation of parameters

\begin{tabular}{|c|c|c|c|c|c|c|c|c|c|c|c|c|c|c|c|}
\hline & pH & EC & TDS & WT & $\mathrm{Ca}^{2+}$ & $\mathrm{Mg}^{2+}$ & $\mathrm{Na}^{+}$ & $\mathbf{K}^{+}$ & $\mathrm{NH}_{4}$ & $\mathrm{HCO}_{3}^{-}$ & $\mathrm{Cl}^{-}$ & $\begin{array}{l}\mathrm{SO}^{2-} \\
4\end{array}$ & $\mathrm{NO}^{3}$ & $\begin{array}{l}\mathbf{P O}^{3-} \\
4\end{array}$ & $\overline{F^{-}}$ \\
\hline $\mathrm{pH}$ & 1 & & & & & & & & & & & & & & \\
\hline EC & $0.82 * *$ & 1 & & & & & & & & & & & & & \\
\hline TDS & -0.11 & -0.26 & 1 & & & & & & & & & & & & \\
\hline WT & 0.54 & $0.69 *$ & -0.48 & 1 & & & & & & & & & & & \\
\hline $\mathrm{Ca}^{2+}$ & 0.66 & $0.89 * *$ & -0.23 & 0.485 & 1 & & & & & & & & & & \\
\hline $\mathrm{Mg}^{2+}$ & $0.68^{*}$ & $0.91 * *$ & -0.23 & 0.526 & $0.99 * *$ & 1 & & & & & & & & & \\
\hline $\mathrm{Na}^{+}$ & 0.457 & 0.704 & -0.21 & 0.45 & $0.84 * *$ & $0.85^{* *}$ & 1 & & & & & & & & \\
\hline $\mathrm{K}^{+}$ & 0.42 & $0.64 *$ & -0.18 & 0.38 & $0.84 * *$ & $0.83 * *$ & 0.88 & 1 & & & & & & & \\
\hline $\mathrm{NH}_{4}$ & -0.16 & -0.21 & -0.13 & -0.42 & -0.22 & -0.19 & -0.21 & 0.14 & 1 & & & & & & \\
\hline $\mathrm{HCO}_{3}^{-}$ & $0.807 * *$ & $0.99 * *$ & $\begin{array}{l}- \\
0.267\end{array}$ & 0.679* & $0.909 * *$ & $0.92 * *$ & $0.72 * *$ & 0.661 & -0.2 & 1 & & & & & \\
\hline $\mathrm{Cl}^{-}$ & 0.02 & -0.28 & $0.59 *$ & -0.49 & -0.20 & -0.21 & -0.027 & -0.64 & 0.11 & -0.28 & 1 & & & & \\
\hline $\mathrm{SO}_{4}^{2-}$ & -0.38 & -0.45 & 0.23 & -0.46 & -0.41 & -0.39 & -0.38 & 0.17 & -0.45 & -0.18 & $\begin{array}{l}- \\
0.16\end{array}$ & 1 & & & \\
\hline
\end{tabular}




\begin{tabular}{|l|l|l|l|l|l|l|l|l|l|l|l|l|l|l|l|}
\hline $\mathrm{NO}^{3}$ & $0.66^{*}$ & $0.576^{*}$ & -0.13 & 0.46 & 0.4 & 0.39 & 0.04 & - & -0.2 & 0.56 & - & - & 1 & & \\
\hline $\mathrm{PO}^{3}{ }^{-}$ & $0.65^{*}$ & $0.9 * *$ & -0.29 & $0.62^{*}$ & $0.78^{* *}$ & 0.77 & $0.64^{*}$ & 0.56 & -0.24 & $0.9 * *$ & - & 0.43 & 0.41 & 0.4 & 1 \\
\hline $\mathrm{F}^{-}$ & $0.58^{*}$ & 0.36 & 0.24 & 0.12 & 0.26 & 0.26 & 0.24 & 0.32 & 0.075 & 0.35 & $0.6^{*}$ & - & 0.32 & 0.24 & 1 \\
\hline
\end{tabular}

$* * 0.05$ level of significance and * 0.01 level of significance

\section{Microbial Quality}

The microbial analysis indicated that all water points in March/July 2015 had detectable levels of coliform count between 9 to $>1100$ MPN (Table 7) with springs having greater contamination than taps. Tcfu varied seasonally, with an increase observed in the wet season than during the dry season especially from Agyati, Ntabuwe, and Mbebali (Table 7). Unlike the first interval 58.3\% of the water sources remained contaminated during the second interval of the study and $41.7 \%$ of the samples were free from coliform contamination in the dry season, remarkably Mbebali/Nchum/Manji, Nsem and Ntabuwe schemes (Table 7).

Table 7: Seasonal variations in Total Coliform counts from water sources

\begin{tabular}{|l|l|l|l|}
\hline Samples & MPN for March2015 & MPN for July2015 & Tcfu March 2018 \\
\hline Mbebali/Nchum/Manji Tap & 460 & $>1100$ & 0 \\
\hline Niko/Njinteh Tap & $>1100$ & $>1100$ & 1 \\
\hline Bujung/Mankaha Tap & 1100 & 1100 & 2 \\
\hline Nsem Tap & $>1100$ & $>1100$ & 0 \\
\hline Ntabuwe Tap & 93 & $>1100$ & 0 \\
\hline Agyati Tap & 43 & 1100 & 6 \\
Mbebali/Nchum/Manji Spring & $>1100$ & & 0 \\
Niko/Njinteh & & & \\
Spring & 460 & & 3 \\
Bujung/Mankaha Spring & $>1100$ & & \\
Nsem Spring & $>1100$ & & 6 \\
Ntabuwe Spring & 210 & & 4 \\
Agyati Spring & 9 & 0 \\
& & \\
\hline
\end{tabular}

Bacterial growth was visible within 48 hours on the Macconkey, SS and Voilet red bile agar. During the second interval $25 \%$ of the samples were within WHO guideline of zero coliform per $\mathrm{ml}$ of water (Table 8). The mean colony forming unit per $\mathrm{ml}$ was $10.26 \mathrm{cfu} / \mathrm{ml}$. it was also noticed that total plate count recorded at least $1 \mathrm{cfu} / \mathrm{ml}$ on $61.9 \%$ of the samples. E.coli was the most abundant bacterial found in water samples and $16.6 \%$ for salmonella. Notably Mankwi borehole observed $236 \mathrm{Tcfu}$ and rain water 16-20 Tcfu/ml.

Computed results of data on water-borne diseases from 2 Health Units, in the study area, suggested the presence of intestinal pathogens in water, which may account for diarrhoea, dysentery through intestinal infections in patients. The most common of these illnesses was intestinal infections, mainly affecting children. With regards to patient's record reviewed (1879 patients) from 2003 to 2015 from the Government Hospital at Manji and from the Presbyterian hospital Nsem. 
Table 8: Bacteriological quality of water second interval March 2018

\begin{tabular}{|l|l|l|l|}
\hline Community/water resource & TCfu & E.coli & Salmonella typhi \\
\hline Mforya HC tap & 2 & $\dagger$ & \\
\hline Manka N spring & 0 & & $\dagger$ \\
\hline Mankwi spring & 0 & & \\
\hline GHS Obang spring & 3 & $\dagger$ & \\
\hline Akossia tap & 5 & $\dagger$ & \\
\hline Niko tap & 1 & $\dagger$ & $\dagger$ \\
\hline Nsem tap & 0 & & \\
\hline Mundum spring & 60 & $\dagger$ & \\
\hline Manka tap & 2 & $\dagger$ & \\
\hline Akossia spring & 0 & & \\
\hline Mankwi tap & 0 & & \\
\hline Nta ya New spring & 1 & $\dagger$ & \\
\hline Ntabuwe tap & 0 & & \\
\hline Tingho HC spring & 3 & $\dagger$ & \\
\hline Nchum tap & 0 & & $\dagger$ \\
\hline Rain water 1 & $\mathbf{1 6}$ & $\dagger$ & \\
\hline Nta ya old spring & 7 & $\dagger$ & \\
\hline Njimbee spring & 0 & & \\
\hline Agyati tap & 6 & $\dagger$ & $\dagger$ \\
\hline Mundum tap & 1 & $\dagger$ & \\
\hline Mankwi borehole & $\mathbf{2 3 6}$ & $\dagger$ & \\
\hline Mambu Bafcul well & 0 & & \\
\hline Mforya stream & 3 & $\dagger$ & \\
\hline Obang stream & 5 & $\dagger$ & \\
\hline Mforya well & 0 & & \\
\hline Mbakong HC well & 3 & $\dagger$ & \\
\hline Adiemukong tap & 0 & & \\
\hline Tingho stream & 17 & $\dagger$ & \\
\hline Mambu nechu well & 0 & & \\
\hline Nchoho tap & 0 & & \\
\hline Obang Alabam stream & 3 & $\dagger$ & \\
\hline Nchoho stream & 0 & & \\
\hline Njimbee Plan well & 0 & & \\
\hline Mbakong big water & 5 & $\dagger$ & $\dagger$ \\
\hline Tingho tap & 5 & $\dagger$ & \\
\hline Niko spring & 3 & $\dagger$ & $\dagger$ \\
\hline Nsem spring & 4 & $\dagger$ & \\
\hline Ntabuwe spring & 2 & $\dagger$ & \\
\hline Mankaha spring & 6 & $\dagger$ & \\
\hline Nchum spring & 0 & & $\dagger$ \\
\hline Agyati spring & 17 & $\dagger$ & $\dagger$ \\
\hline Rain water 2 & $\mathbf{2 0}$ & $\dagger$ & \\
\hline
\end{tabular}


At least one of the causative agents which results to water-borne diseases (Salmonella typhi, Escherichia historic, Escherichia coli and Coli Bacilli) were identified in $87 \%$ of patients, E. coli $40 \%$ and Salmonella typhi 39\%. Prevalence of Salmonella typhi was eminent in women $(66.8 \%)$ mostly from Mbebali, Nchum and Manji (Figure 5).
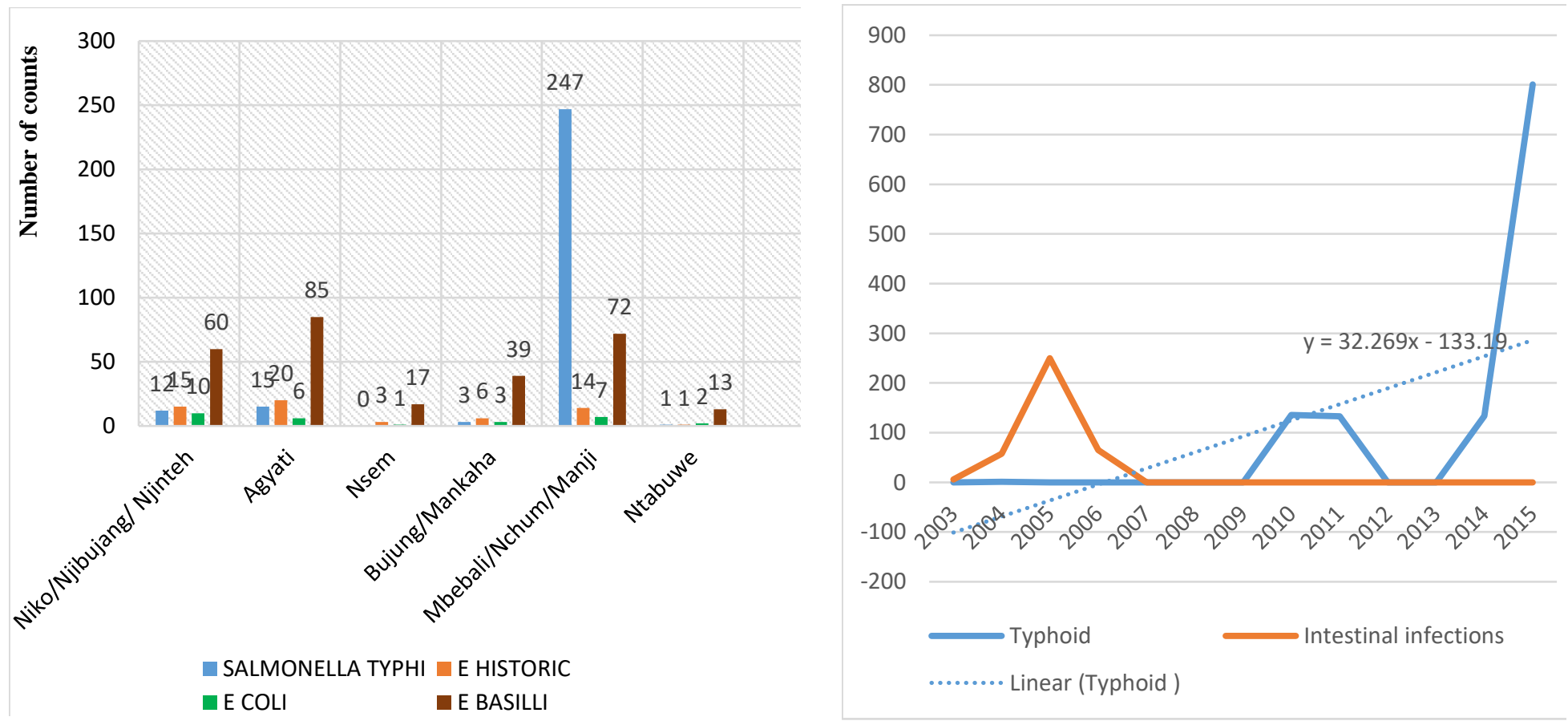

Figure 5: Water borne diseases causative agents and trend

The health consequences may also be felt by adults but as common in rural settings of Cameroon, most people go for traditional herbs in case of (waterborne) infections. Also, most people might have adapted to this poor water quality such that the most vulnerable are children and likely new users. Adult (+30year) were more inclined to all causative agents particularly Salmonella typhi (54\%) and infants within the ages of 0-5years (23\% of patients) had Coli bacilli and Salmonella typhi infection. Typhoid had an increasing trend of occurrence from $7.4 \%$ in 2010 to $43.3 \%$ in 2015. Coli basilli, Escherichia historic and Escherichia coli observed a decreasing trend due to a transit of test to basically salmonella typhi from 2007-2015.

\section{Discussion}

The population within the study area depends on pipe-borne water (97\%) from springs for domestic activities (98.5\%) such as cooking, bathing and drinking. This is similar to the results of Fitsum and Fikirte, (2014), in rural Ethopia who equally found that the communities either use rivers or unprotected springs for their domestic water supplies. Most of the water supply schemes within the study area were constructed about 20 years ago financed by the community and None Governmental Associations (SATA-HEVETAS and Plan International). 
The challenges of potable water supply management included; Burst pipes, unplanned development, slope gradients, old existing pipe line and low finance. Henry, (2007), in a study of Assessing the Challenges of Water Supply in Ghana observed that bad pumps and low slope gradients, low input from springs and change in land use wherein forested areas became areas of inhabitation, accordingly led to water crises in Ghana. Challenges of potable water supply was also triggered by variations in rainfall from $2,825 \mathrm{~mm}$ in 1995 to $2,250 \mathrm{~mm}$ in 2015 , which could lead to a drop in the water table thereby reducing discharge from springs. This is in conformity with Ngounou et al., (2005), in their study of climate variability and impacts on an alluvial aquifer that precipitation has a positive impact on aquifer water level. In addition, Ayonghe, (2001), observed that seasonal variability of climate is one of the most challenging pressures facing hydrological systems and water resources.

Although WHO (2012) and UNICEF, (2012) guideline for water, states that an individual should have a daily water consumption need of 20 litters per day within $1 \mathrm{~km}$ from household, this study indicated a low supply coverage of $9.5 \%$ and 6.5 liters, indicating less quantity of water and outreach to the entire population. Following these guidelines, none of the supply system could meet up to 20 liters of water per individual in a day. This is similar to the results of Henry, (2007) in Ghana with a daily water need of 8 liters per person in a day.

With regards to the physico-chemical properties the 24 water samples had a $\mathrm{pH}$ range of 6.7-7.75 implying they are acidic, which according to Ebbing, (1990), a pH of less than 7 are acidic and solutions with a $\mathrm{pH}$ greater than 7 are basic. In addition, according to Taiwo et al., (2012) the $\mathrm{pH}$ range of these water samples falls within the WHO, (2012) guideline for drinking water quality of 6.5 to 8.0 .

The concentration of calcium and magnesium showed a correlation value of 0.997 , implying that they come from a similar source, possibly igneous rocks particularly basalts found in the study area. This correlation value also explains the abundance of magnesium $(0.02 \mathrm{meq} / \mathrm{l}-2.2 \mathrm{meq} / \mathrm{l})$ and calcium $(0.002 \mathrm{meq} / \mathrm{l}-1.81 \mathrm{meq} / \mathrm{l})$ in the water sources because these are the most abundant cations found in most igneous rock types with high solubility. This is in accordance with Marskak, (2007), who illustrated that igneous rocks are often dominated by magnesium and calcium minerals. Sodium concentration varied from 0.7 to $1.9 \mathrm{mg} / \mathrm{l}$ while that of potassium varied from $0.61 \mathrm{mg} / \mathrm{l}$ for Ntabuwe spring (NTS) to $1.82 \mathrm{mg} / \mathrm{l}$ for Niko/Njinteh tap (NNT). Potassium had a positive correlation with sodium $(\mathrm{r}=0.88)$ signifying that their concentrations are directly related. This ties with Pidwirny, (2007), whose study showed that felsic magma such as rhyolites and granites are usually rich in sodium and potassium. This direct relationship indicates the presence of sodium and potassium bearing minerals from rhyolites and granites in the study area.

The concentration of bicarbonate, ranged from 8.1 for AGT to $116.3 \mathrm{mg} / \mathrm{l}$ for MKS. This exceptional high concentration could be attributed to the dissociation of common salt deposits in geologic formations exemplified in the work of Witzel, (2001). The results also indicated that chemical elements were significantly correlated with $\mathrm{HCO}_{3}^{-}$, which could be an indication that the aquifer system may have experienced various processes such as ion exchange, and water-rock interaction (Nally et al., 2004). 
Chloride concentration ranged from 0.03 to $0.23 \mathrm{mg} / \mathrm{L}$, with highest concentration from Agyati spring (AGS). Chloride in groundwater comes from both natural and anthropogenic sources such as the use of inorganic fertilizers, landfill leachates, septic tank effluents, animal feeds, leaching during rainfall, industrial effluents, irrigation drainage, and seawater intrusion (Malin and Carl, 1992). However this concentration was far above the WHO threshold of $250 \mathrm{mg} / \mathrm{l}$ making it safe for drinking.

Concentration of nitrate in the study area was found to be comparatively low, ranged from 0 to $1.55 \mathrm{mg} / \mathrm{l}$ from Nsem tap (NST) and 0 to $0.9 \mathrm{mg} / \mathrm{l}$ for ammonium. The source of nitrates can usually be traced to agricultural activities and human wastes as observed in the study of Oslon, (2012).

The major chemical elements found in volcanic rocks particularly basalts are magnesium, calcium, sodium and potassium (Hem, 1989), giving reasons for the dominant water types being sodium/potassium water type, magnesium water type and bicarbonate water type. These water samples were made up of two hydro chemical facies, including sodium bicarbonate and calcium chloride groundwater (Figure 4). This signifies that they are from granitic and basaltic rocks rich in sodium potassium, calcium and magnesium from a natural origin (Prasad et al., 2009).

This study recorded the presence of coliform in all water sources during the first interval for March and July 2015 indicating contamination. WHO drinking water guideline standardizes zero coliform per $100 \mathrm{ml}$ (WHO, 2012), thus rendering water sources unsuitable for drinking. This is similar to the results of Okonko et al., (2008) indicating the presence of coliforms in potable water. There was a significant increase in the number of coliform found in tap water within the months of July and March 2015. This seasonal variation could be as a result of increase runoff and infiltration into springs coupled with burst pipes during water distribution.

During the second interval of the study, coliform was also observed in the water samples, with higher concentrations from springs than taps. The presence of coliform confirmed by the detection of Escherichia coli served as an indication of faecal contamination in the water. This could be attributed to the location of latrines close to the catchment area and reservoir tanks. This is similar to the studies of Egwari and Aboaba, (2002), on the environmental impact of bacteriological quality of domestic water supply in Lagos, that organism contained in waste water such as those from latrine are responsible for health defects in children. The detection of high total coliform count in water samples could also be attributed to climate based on a mean water temperature of $22.5^{\circ} \mathrm{C}$, which could boost bacteria growth in water. This is similar to the study of Mengnjo et al., (2013), that warm climate and water temperature increase bacteria growth in unconfined aquifers. The unprotected structural nature of the catchment also provides a suitable ground for bacterial infection.

The detection of Escherichia coli and Salmonella in the water samples, with Salmonella observed on 7 samples was remarkable. At least one causative agent for water borne diseases (Salmonella typhi, Escherichia historic, Escherichia coli and Coli bacilli) were identified in $87 \%$ of patients' laboratory results. Escherichia coli recorded $40 \%$ and Salmonella typhi 39\% which could be responsible for water borne diseases such as cholera, typhoid and diarrhea. The prevalence of typhoid which results from Salmonella typhi was eminent in women (66.8\%) due to their exposure to water for domestic activities. At the third World Water Forum in Kyoto (2003) it was recognized 
that, in addition to being prime users of "domestic water", women used water in their key role in food production and that women and children are most vulnerable to water-related disasters.

High prevalence of typhoid was renowned in Mbebali, Nchum and Manji communities where the water catchment has been encroached by inhabitants. Infants within the ages of 0-5years (23\% of patients) had coli bacilli and Salmonella typhi infection, this could be attributed to feeding during pregnancy from the mothers as reported in WHO, (2011). Egwari and Aboaba, (2002), in their study on environmental impact of bacteriological quality of domestic water supply in Lagos, explained that children less than 5 years old are the most vulnerable to water-borne diseases.

Although rain water can be one of the alternative sources of drinking water due to its low level of contamination and mineral content as compared to water from fountains could be a vehicle to potential health risk (Carolyne and Kui, 2015). However this study indicates that Escherichia coli contamination was present in rain water which could be attributed to dust particles absorbed by water particles in the atmosphere.

\section{Conclusions and Recommendations}

Water supply in the study area was grossly inadequate due to multiple reasons; population growth which the old pipelines cannot support, dilapidated pipes, activities carried out in the catchment area, unplanned developments of springing communities, illegal connections, dilapidated pumps and less input from springs. Natural factors such as climate variability accounted for shortage in water supply. This shortage was in conformity with a 9.5\% supply coverage and an average of 6.5 liters of water per individual.

Water quality assessment per chemical and physical parameters was generally lower than the WHO recommended limits for potable water. The main water type was Sodium Bicarbonate for ground water. The ionic concentrations in the water was largely based on the geology of the area, rain fall input and atmospheric conditions which is largely influenced by climate.

Springs and taps had a Total Coliform count of 43 to $>1100$ per 100ml in March and July, 2015 with more counts in springs than taps in March. The concentration of bacterial was greater in the rain season than the dry season probably due to runoff infiltration in the springs. Nearness of catchment area to latrines and laundry carried out at some of the taps/springs coupled with water temperatures could be accountable for high levels of coliform counts in the water sources.

Escherichia coli and Salmonella typhi were the main bacteria found in water samples which accounts for the high prevalence of water borne diseases particularly typhoid which affects children.

Water supply schemes were found to be contaminated during the first interval (March- August 2015) and the second interval (March 2018). The Microbial quality of the water supply schemes were poor and not suitable for drinking and a public health concern following WHO guideline for drinking water. There is need for a Standardized Water Resource Management Policy and an implement of Integrated Water Resources Management (IWRM) plan. 


\section{Acknowledgements}

Our utmost gratitude to Laboratoire d'Analyse Geochemie et l'Eau (LAGE) for the chemical analyses of water samples and the Life Science Laboratory of the University of Buea. Partial funding towards the realisation of this study was provided by the USAID/PERIPERI U grant through the UBuea Consortium.

\section{References}

[1] Ako, A, Shimada. J, Eyong G.E And Fantong W. (2010). Access to Potable Water and Sanitation in Cameroon Within The Context Of Millennium Development Goals (Mdgs). Journal Of Water Science And Technology, 61(5):1317-39.

[2] Ako Aa, Nkeng Eg, Takem, G.E. (2009). Water Quality and Occurrence of Waterborne Diseases in The Douala 4th District, Cameroon. Water Sci. Technol., 59(12): 2321-2329.

[3] American Public Health Association. (1985). Standard Methods for The Examination of Water and Waste Water. Section 908 And 909.16 ${ }^{\text {th }}$ Edition,Apha, Washington, D.C

[4] Bafut Council Office. (1964): Files on The Classification of Cases at Njinteh. Bafut Sub-Division Bamenda Cameroon

[5] Benson, H.J. (2002). Microbiological Application. Laboratory Manual in General Microbiology. $8^{\text {th }}$ Edition, Mc. Graw Hill Companies, New York.

[6] Carolyne, P and Kui, J. M. (2015). Consumption of Rain Water Harvesting in Terms of Water Quality. International Journal of Geomate. Vol 9, No. 2

[7] Centre for Affordable Water and Sanitation Technology. (Cawst, 2009): Introduction to Drinking Water Quality Testing. Journal of Drinking Water Quality Research Foundation United States.

[8] Council Development Plan. (Cdp, 2011). An Elaborate Report with The Support of The National Community Driven Development Programme (Pndp).

[9] Djaouda, M.; Njiné, T.; Liang, S.; Ebang Menye, D.; Gaké, B.; Zébazé Togouet, S.H.; Nola, M. (2014). Bacteriological Quality of Well Waters in Garoua, North Cameroon. Water Qual. Expo. Health 2014, 6, 161-176.

[10] Domenico, P.A., Schwartz, F.W. (1990). Physical and Chemical Hydrology. John Wiley and Sons. 411:485-497.

[11] Druce, R.G, Nancy, B.B, Elson, K.J and Harcombe, S.B. (1957). The Determination of The Coli Aerogenes Content of Milk and Dairy Equipment by Plating on Violet Red Bile Agar Incubated At $30^{\circ}$. Journal of Applied Bacteriology. Vol 20 No 1

[12] Egwari, L.O., Iwuanyanwu, S., Ojelabi, C.I., Uzonchukwu, O and Effiok, W.W. (2005). Bacteriology of Sachet Water Sold in Lagos, Nigeria. East African Medical Journal.85: 235-240.

[13] Fewtrell, L., Prüss-Üstün A, Bos R, Gore F, Bartram J. (2007). Water, Sanitation and Hygiene: Quantifying the Health Impact at National and Local Levels In Countries With Incomplete Water Supply And Sanitation Coverage. Environmental Burden of Disease Series, Who, Geneva. No. 15

[14] Fitsum, D. K and Fikirte, D. T. (2014). Challenges of Potable Water Supply System in Rural Ethiopia: The Case of Gonji Kolela Woreda, West Gojjam Zone, Ethiopia. Natural Resources and Conservation. Horizon Research Publishing. Journal of Natural Resources and Conservation Vol. 2(4), Pp. 59 - 69

[15] Gereta, E.J. (2004). The Importance of Water Quality and Quantity in The Tropical Ecosystem Tanzania. Norwegian University of Science and Technology Trondheim.

[16] Gleick, P.H. (1996). Water Resources. In Encyclopaedia of Climate and Weather. Oxford University Press, New York Vol 2.

[17] Harvey, R. (2007). Community-Managed Water Supplies in Africa: Sustainable or Dispensable? Community Development Journal Vol 42 No 3 
[18] Hem H.D (1989), Study and Interpretation of The Chemical Characteristics of Natural Waters. ( $3^{\text {rd }}$ Ed). U.S. Geological Survey Water-Supply Paper 2254.

[19] Henry, W. D. (2007) Assessing the Challenges of Water Supply in Urban Ghana: The Case of North Teshie. Royal Institute of Technology (Kth) Stockholm, Sweden.

[20] Katte Vy, Fonteh Mf, Guemuh Gn (2003). Domestic Water Quality in Urban Centres in Cameroon: A Case Study of Dschang In the West Province. Afr. Water Journal. Pilot Edition: 43-54.

[21] Kuitcha D, Kamgang Kbv, Sigha Nl, Lienou G, Ekodeck Ge (2008). Water Supply, Sanitation and Health Risks in Yaounde, Cameroon. Afr. J. Environ. Sci. Technol., 2(11): 379-386.

[22] Kuitcha D, Ndjama J, Tita Am, Lienou G, Kamgang Kbv, Ateba Bh, Ekodeck Ge (2010). Bacterial Contamination of Water Points of The Upper Mfoundi Watershed, Yaounde, Cameroon. Afr. Journal. Microbiol. Res., 4(7): 568574.

[23] Malin, Falkenmark And Carl Widstrand. (1992)."Population and Water Resources: A Delicate Balance": Washington, Dc: Population Reference Bureau.

[24] Marshak, Stephen (2007). Essentials of Geology, 2nd Ed, W. W. Norton. 545p

[25] Mengnjo, J.W, Ayonghe, S.N, Engome, R.W, Takeshi, O, Fantong, W.Y (2013). Sources of Bacteriological Contamination of Shallow Groundwater and Health Effects in The Ndop Plain North West Cameroon. Journal of Environmental Science and Water Resources. Vol. 2(4) Wudpecher Journals.

[26] Michel, W. (2017). Intercomparison Of Regional Scale Hydrological Models and Climate Change Impact Project For 12 Large River Basins Worldwide.

[27] Nally, W.H and Methta, A.J. (2004). Sediment Transportation and Deposition in Estuary. Vol 11 Pp 78-91

[28] Neba, A. (1999). Modern Geography of The Republic of Cameroon. Neba Publishers P.O Box 778 Bamenda North West Province.

[29] Ndenecho, E.N (2007). Upstream Water Resource Management Strategy and Stakeholders Participation. Bamenda, Cameroon: Agwecam Printers. 250p

[30] Ndjama J, Kamgang K.B.V, Sigha N.L, Ekodeck G, Awah T.M (2008). Water Supply, Sanitation and Health Risk in Douala, Cameroon. African Journal of Environmental and Technology, Vol2(12):422-429.

[31] Nforba, M., Kabeyene, V and Suh, C. (2011). Regolith Geochemistry and Mineralogy of The Mbalam Itabirite-Hosted Iron Ore District, South Eastern Cameroon. Open Journal of Geology, Vol. 1 No. 2, 2011, Pp. 17-36.

[32] Ngwa Nebasina Emmanuel. (1982). Rural Geography of The Bafut Chiefdom. Yaounde Cameroon.

[33] Ngounou, N.B, Mudry, J., Sigha, L.N., Njitchoua, R and Naah, E. (2005). Climate Variability and Impacts on An Alluvial Aquifer In A Semi-Arid Climate, The Logone-Chari Plain (South Of Lake Chad). Regional Impacts of Climate Change - Impact Assessment and Decision Making. Publish. 296 Isbni-901 1502-13-9. Pp94-100.

[34] Njunda, L.A., Jules, C.N., Nsagha,D.S., Ngene, B.A And Tebit, E.K. (2013). Bacteriological Analysis of Drinking Water in The Cameroon Development Corporation (Cdc) Penda Mboko. American Journal for Integrated Health Care, 02:26-31

[35] Nola, M.; Nougang, M.E.; Noah Ewoti, O.V.; Moungang, L.M.; Krier, F.; Chihib, N.-E. (2014) Detection of Pathogenic Escherichia Coli Strains in Groundwater in The Yaoundé Region (Cameroon, Central Africa). Water Environ. Journal.2013, 27, 328-337.

[36] Okonko, I.O., Adejoye, O.D., Ogunnusi, T.A., Fajobi, E.A and Shittu, O.B. (2008). Microbial and Physiochemical Analysis of Different Water Samples Used for Domestic Purposes in Abeokuta And Ojota, Lagos State, Nigeria. African Journal of Biochemistry.

[37] Omam, C.M and Ayonghe, S.N. (2015). An Assessment of The Potability Of Some Sachet Water Brands Sold in Cameroon. Journal of The Cameroon Academy of Science, Vol.12 No.3

[38] Olson R. J, D.L. Hughes, J.A. Gore, And M.P. Brossett. (2010). Candidate Reference Conditions. Rapid Bio Assessment of Stream Health. Crc Press, Boca Raton, Florida. Chapter 4. 
[39] Patricia, B. (2014). Water Our Most Important Natural Resource. The Green Dandelion. University of Rochester.

[40] Pidwirnymicheal. (2006). "Characteristics of Igneous Rocks". Fundamentals of Physical Geography. $2^{\text {nd }}$ Edition.

[41] Piper, A.M. (1984). A Graphical Proceduce In the Geochemical Interpretation of Water Analysis Trans. Am. Geophysical Union, In Ground Water Quality Series: Vol 25, 914-1923

[42] Regassa A. E. (2016): Income Determinants of Irish Potato (Solanum Tuberosum L.) Growers: The Case of West Arsi Zone of Oromia Regional State, Ethopia. Net Journal of Agricultural Science, 4(1): 1-8.

[43] Scott, J And Richard,G.T. (2015). Intensive Rainfall Recharges Tropical Ground Water. Environmental Research Letters. Science Daily.

[44] Small, H., Stevens, T.S and Bauman, W.C. (1975). Novel Ion Exchange Chromatography Method Using Conductimetric Detection. Analytical Chemistry 47:1801-1809.

[45] Strasser, Balz. (2000). Keeping the Water Flowing: A Sociological and Financial Analysis of Financing Infrastructure, Operation and Maintenance of A Rural Water Supply Scheme: The Case Study Of Kedjom Ketinguh In The Northwest Province Of Cameroon. Wageningen University

[46] Sophocleous, Marios (2002). "Interactions Between Groundwater and Surface Water: The State of The Science". Hydrogeology Journal 10: 52-67.

[47] Takem, G.E.; Chandrasekharam, D.; Ayonghe, S.N.; Thambidurai, P. (2010). Pollution Characteristics of Alluvial Groundwater from Springs and Bore Wells in Semi-Urban Informal Settlements of Douala, Cameroon, Western Africa. Environ. Earth Sci. 2010, 61, 287-298.

[48] Taiwo. A.A., Idowu, O., Lanre-Iyanda, Y.A., Jolaoso, A. A., Jiboku, O.O., T.O. And Taiwo, A.G. (2012). Physico Chemical and Bacteriological Analyses of Sachet Water Samples in Abeokuta Metropolis. Global Advance Research Journal of Agricultural Science, 1(1): 001-006.

[49] Temgoua E (2011). Chemical and Bacteriological Analysis of Drinking Water from Alternative Sources in The Dschang Municipality, Cameroon. Journa Environ. Prot., 2: 620-628

[50] Unicef/Who (2012). Progress on Drinking Water and Sanitation: Joint Monitoring Program for Water Supply and Sanitation. Unicef, Newyork.

[51] World Health Organization. Preventing Diarrhoea Through Better Water, Sanitation and Hygiene: Exposures and Impacts in Low and Middle-Income Countries; Who: Geneva, Switzerland, 2014; Pp. 1-48.

[52] Who and Unicef (2000): Global Water Supply and Sanitation Assessment 2000 Report World Health Organization and United Nations Children's Fund, 2000.

[53] World Health Organization (2011): Taking Sex and Gender into Account In Emerging Infectious Disease Programme: An Analytical Framework. All Rights Reserved. Who Press, 20 Avenue Appia, 1211 Geneva 27, Switzerland

*Corresponding author.

E-mail address: samayonghe @yahoo.com 